\title{
Feasibility of Negotiating Social Security Agreement with Other Countries: Example of the Labor Insurance in Taiwan
}

\author{
Ke-Jeng Lan, Chi-Hsin Wü, Tsai-Chuan Ma \\ Department of Labor Relations, National Chung Cheng University, Taiwan \\ Email: osmond@mai12000.com.tw
}

Received December 16, 2013; revised January 16, 2014; accepted January 23, 2014

Copyright (C) 2014 Ke-Jeng Lan et al. This is an open access article distributed under the Creative Commons Attribution License, which permits unrestricted use, distribution, and reproduction in any medium, provided the original work is properly cited. In accordance of the Creative Commons Attribution License all Copyrights @ 2014 are reserved for SCIRP and the owner of the intellectual property Ke-Jeng Lan et al. All Copyright (C) 2014 are guarded by law and by SCIRP as a guardian.

\section{ABSTRACT}

This research analyzes the social security agreements negotiated by other countries, and evaluates the feasibility of negotiating such agreement with respect to the Labor Insurance in Taiwan. In consideration of administrative and political factors, some prerequisites have to be achieved to realize such feasibility. Due to imminent demand to negotiate such agreement, some suggestions are provided. 1) Short-term strategies: Plan to analyze the impacts of double insurance exemption on stakeholders. 2) Medium-term strategies: implement ameliorated Labor Insurance statistics, try to complete the negotiation of social security agreements of double insurance exemption. 3) Long-term strategies: Plan to apply totalization mechanism among various social insurances.

\section{KEYWORDS}

\section{Social Security Agreements; The Labor Insurance; Migrant Workers; Adoption of Oversea Social Insurance} Tenure

\section{Introduction}

The social security insurance of the migrant labor received the attention very early. For example, ILO No. 48 Convention in 1935 advocated constructing the social security maintaining the old, the handicapped, the widowed, and the orphan; ILO No. 102 "Social Minimum Standard Convention" in 1952 required that, under the principle of the national treatment (as well as the principle of reciprocity, referring to ILO No. 118 "Social Security Fair Treatment Convention" in 1962), the foreign resident shall enjoy the same minimum social security as the national resident; ILO No. 151 "Migrant Labor Proposal” in 1975 claimed that the departed migrant labor shall acquire the deserved social security payment, otherwise it shall return the insurance premium; ILO No. 157 "Social Security Rights Maintenance Convention" in 1982 proposed that it shall take account of the tenure of additional social insurance in other countries, to promote transnational portability; No. 167 Proposal in 1983 point-

*Corresponding author. ed out that the short-term (within two years) assigned employee shall just be specified by the laws of mother country.

Along with the development of globalization, the amount of transnational mobile employment increases a lot, and all circles more and more concern about the rights and interests of the migrant labor, hoping to accelerate the smooth transnational mobile employment; the transnational enterprises also care for the burden of personnel costs of double social insurances of employees in their mother countries and the working country; however, only depending on the native laws to guarantee the rights and interests of migrant labors (such as the adoption of overseas social insurance tenure), and the deduction in personnel cost of double insurance by the transnational enterprise, is imperfect; hence, the advanced countries prior negotiate the Social Security Agreement with the corresponding rival countries with many migrant labors, such as, Italy [1] and UK [2], etc.

The quantity of overseas employment of Taiwan in- 
creases rapidly in recent years ${ }^{1}$. But Taiwan presently has not signed any Social Security Agreement with other countries. Whether the Taiwan residents working in other countries are able to or forced to purchase the local social insurance or not, and whether they could acquire the payment qualification or not after purchased, they depends on the regulation of the working country. The social insurance tenure of the working country for overseas employment could not be calculated as the tenure of Labor Insurance in Taiwan (hereinafter referred to as the Labor Insurance) at present. In the aspect of purchasing the Taiwan Labor Insurance for the overseas employment, the insured could absolutely keep the Labor Insurance if he/she maintains the employment relation with the Taiwan parent company while assigned to other countries for inspection, studying or service; however, the person working in the overseas company and drawing salary form the overseas company, with no more employment relation to the Taiwan parent company, shall not keep the Labor Insurance in the parent company. Some labors would change to purchase the Insurance in the trade union to accumulate the tenure of qualification for old-age benefit and other payments, but this way does not conform to the provision of Labor Insurance Act. If the Taiwan labor with overseas employment could not maintain the Labor Insurance, the old-age benefit tenure and corresponding payment would be low; and if the Taiwan labor with overseas employment does not purchase the social insurance in neither Taiwan nor the working country, their old-age benefit tenure and corresponding payment would be lower; these would cause the problem of insufficient social security.

For another aspect, for the Taiwan labor able to purchase the social insurance for overseas employment, there may be the conditions as not acquiring the reasonable old-age benefit for insufficient tenure, or the social insurance payment of other countries inferior to Taiwan. For example, the endowment insurance of China shall give personal account and social integrated payment with certain payment tenure; if the payment tenure is insufficient, it could just get the one-time payment accumulated in the personnel account. While for the provision difference of the mother country and working country to the mandatory social insurance, there is the danger of double insurances if the Taiwan labor with overseas employment needs to pay for the social insurances both in Taiwan and the working country; and if the Taiwan labor could not acquire the social insurance payment of the working country, the labor and the employer may have the danger of double burden; therefore, the rights and interests of Taiwan labor with overseas employment and the em-

\footnotetext{
${ }^{1}$ There is no statistics of the quantity of overseas employment of Taiwan labor. According to the survey of the Council of Labor Affairs, there is estimated 0.6 million to 1.1 million of Taiwan labor to employ in Mainland China.
}

ployer shall be concerned.

Foreigners working in Taiwan shall follow the provision of Item 1 of Article 6 of Labor Insurance Act, that the labor employed by the company or firm over 5 persons shall purchase the labor insurance with the insurance unit of the employer; and Item 3 of the same article specifies that, the aforesaid labor includes the serving foreign employee. Hereunder, the foreign employee shall purchase the labor insurance as required, and enjoy the insurance compensation right when the insured accident occurs. Hence, except for the household foreign labor (including the family foreign care and family foreign helper) ${ }^{2}$, few foreign professionals, and illegal foreign labor, the industrial foreign labor and majority foreign professionals are forced to purchase the Labor Insurance. The foreign labor purchased the Labor Insurance shall enjoy the same benefit (Defined Benefit System) as the national insured. According to the Labor Insurance Act, the insured tenure under 15 years could just draw onetime old-age benefit, rather than the annual old-age benefit; therefore, some persons think that there may be the foreign labor excessively paid the Labor Insurance premium. For the employer, if the foreign labor could exempt some insurance premiums unable to draw the benefit, it could reduce the personnel cost of employer employing the foreign labor, which shall be good for the employer to improve the competitive power. If the foreign labor doing the transnational (such as coming in Taiwan) short-term work (similar to the atypical work type) also needs to purchase the social insurance (such Labor Insurance), it is comparatively troublesome.

Since the globalization trend drives the frequent international labor flow, all countries pay attention to the social security of migrant labors, and some countries have signed the Social Security Agreement, to ensure that the migrant labor of both sides can enjoy the complete social insurance guarantee. For example, the European countries have already had the Social Security Agreement (France and UK signed the Social Security Agreement in 1949) during the World War II; USA has started from 1970s, and has signed agreement with 24 countries; Japan and USA have signed the Social Security Agreement to mutually adopt the insurance tenure in the other country; South Korea has signed the Social Security Agreement with USA and UK separately; the Philippines ${ }^{3}$ also has signed the Social Security Agreement with USA, UK, France and Switzerland; China has signed the Social Security Agreement with Germany and South Korea; and

\footnotetext{
${ }^{2}$ The household foreign labor belongs to the object of voluntary insurance, and the employer usually replaces by the accident insurance, but the accident insurance has no old-age benefit.

${ }^{3}$ In the Association of Southeast Asian Nations (ASEAN), the Indonesia and the Philippines are the largest labor exporting countries, while Singapore and Thailand are the largest labor importing countries, but only the Philippines actively guarantee the social security rights and interests of overseas labors (Mahidol Migration Centre, 2011).
} 
Australia has signed the Social Security Agreement of old-age pension insurance exemption for dual insurance with several countries (the Australian resident working overseas just need the Australian old-age pension insurance, referring to the website of Australian Taxation Office for the Commonwealth of Australia).

The signature of the Social Security Agreement shall consider the quantity of the interested parties and persons, social, economic, and political interests, general domestic and overseas policies, and political feasibility, as well as the social security system in the nature of defined contribution or defined benefits, function of payment and scope, ability to coordinate the relevant regulations, demand of coordinating the relevant regulations, and convenience of the Social Security Agreement, etc.; the content and application of the Social Security Agreement shall consider the national social security structure (such as the competent authority and contacting institute), implementation tool (such as the resident/citizen login-in, foreign language translation, transnational remittance safety), data protection, feasibility of the agreement articles, confirmation of beneficiary identity, verification of beneficiary status, reliable health examination/report /death certificate/birth certificate/family background/income (and wealth), prevention of cheating drawing, adequate information exchange, and complete treatment for dispute, etc. [3].

If Taiwan negotiating to sign the Social Security Agreement is feasible, the agreement would involve in the insurance premium ratio, insured object, payment condition, standard, financial transaction, and fund operation of different social insurance systems, the principle of equality of the insured, and the tenure adoption, etc., so what items of the agreement content shall be considered? The most important old-age pension system in Taiwan is the Labor Insurance. The pension implemented since 2009 obviously increases the old-age income, but also increases the potential financial pressure for Labor Insurance (referring to [4]); so is the signature of Social Security Agreement unfavorable to the current financial status of Labor Insurance of Taiwan? And if the signature of Social Security Agreement of Taiwan is feasible, which countries could be considered as the prior object? Moreover, as the signature of Social Security Agreement is time-consuming, is it possible for Taiwan to amend the relevant Taiwan laws, or remain for the negotiation with other countries?

We settle the two research purposes: 1) To Understand Contents, Notices and Implementation Conditions of Social Security Agreement Signed by Other Countries. 2) Focusing on Labor Insurance, to Discuss Feasibility of Taiwan Signing Social Security Agreement with Other Countries.

This section is the introduction, to explain the research motivation and problem, research purpose, research method, and the section arrangement. The second section is the literature analysis, to introduce the Social Security Agreement, the Social Security Agreement of other countries, and the social security of Taiwan to the foreign labor and the native labor working overseas. The third section is the comparison and analysis of consideration and content of Social Security Agreement of each country and the conformance evaluation of Taiwan Labor Insurance system. The fourth section is the policy suggestions.

\section{Literature Analysis}

\subsection{Social Security Agreement}

The social safety nets, also called the socioeconomic safety nets, originally refer to the non-payment income transfer scheme, aiming at prevention of poverty, or helping the vulnerable groups out of poverty and not trapped in the poverty; the various rescue plans of the socioeconomic safety nets could be provided by the public sectors (such as the government institutions at various levels) or private sectors (such as NGOs, private enterprise, or informal family income transfer) (Wikipedia website). However, in order to expand the degree of guarantee and participation, and reduce the government financial burden, many countries adopt the social insurance system, to strengthen the socioeconomic safety nets. The complete socioeconomic safety nets could guarantee the public enjoying the basic living needs as health, economy, and education, to provide the basic cost of subsistence allowance and dignity for the public, and promote the social stability and harmony, which would greatly affect the national welfare.

The contents of the social security generally include: the medical treatment/injury/occupational injury/disability (health), unemployment, agedness, family, maternity, care for the family dependents survivors of the deceased. The persons without the local nationality, no matter working or living, are easily to be the vulnerable groups, but the applicable social security is usually inferior to those with the local nationality. Therefore, the international society pays attention to the topic of social security of migrant labors very early. For example, due to the increase of transnational employment, the International Labor Organization [5] advocated the social security of migrant labors long time ago, to avoid the migrant labor suffering discrimination. The revealed content ILO Social Security (Minimum Standard) Convention (No. 102) in 1952 included the medical care benefit, injury benefit, unemployment benefit, old-age benefit, occupational injury benefit, family dependents benefit, maternity benefit, disability benefit, and benefit for family dependents survivors of the deceased, among which for the 
old-age benefit with 65-year-old as the upper limit of working, those paid for the premium shall acquire the benefit, and those could not acquire the benefit shall be returned the premium; and it required to fairly treatment to the resident without the local nationality; while in some certain conditions, the benefit payment shall be terminated (if not in domestic, relaying on the public assistance, cheating drawing, committing a crime, or not performing the obligation, etc.), and the seaman and sailor would not be applicable to this convention (because it is applicable to the Social Security Convention and Old-age Pension Convention in 1946).

ILO Employment Injury Benefit Convention (No. 121) in 1964, Benefit Convention of Disability, Agedness and Family Dependents Survivors of the Deceased (No. 128) in 1967, Medical Care and Disease Benefit Convention (No. 130) in 1969, and Employment Promotion and Unemployment Security Convention (No. 168) in 1988, all pointed out that the native resident and foreigner shall enjoy the same rights. Except for these general social security conventions, ILO also passed some special conventions to protect the social security right of international migrant labors, including the Equal Treatment (Accident Compensation) Convention (No. 19) in 1925, Immigrant Pension Rights Protection Convention (No. 48) in 1935, Equal Treatment (Social Security) Convention (No. 118) in 1962, and Social Security Right Protection Convention (No. 157) in 1982. These conventions established 5 basic principles on the basis of the bilateral and multilateral social security agreement:

1) Equality of treatment: The migrant labor shall have the same right and obligation as the general resident in the greatest extent.

2) Determination of the applicable legislation: To establish the applicable social security legislation to the migrant labor in the working country at any time.

3) Maintenance of acquired rights and provision of benefits abroad: The right acquired by the migrant labor in any place shall be reserved, and shall not affect the benefit rights and interests.

4) Maintenance of rights in course of acquisition: If the benefit must meet the standard of qualification duration, the working duration of the migrant labor in every country shall be counted.

5) Reciprocity: the equal treatment among the countries shall be reciprocity. If any country refuses to offer the equal treatment of labors from other countries, it is impossible for its native labor acquiring the equal treatment when working in other countries.

The European advocate of domestic worker rights and interests held the conference in London in 1999, passed the draft prepared by the Domestic Worker Migrant Labor Networking "A Charter of Rights for Migrant Domestic Workers in Europe". The charter emphasized the importance of domestic work to the European family life, economy, and supporting system, and pointed the domestic work is a hard work, that many women leave their family and children to get out of poverty, so their dignity and right as human and labor shall be guaranteed. Although this charter was a broad declaration, it also showed the domestic work migrant labor should enjoy the social protection right [6].

Through the discussion of aforesaid international organizations to the social protection declaration of migrant labor, if the migrant labor shall enjoy the complete social security, there shall be 3 essentials: first, the migrant labor shall have the change to enjoy the same insurance and benefit with the native labor; second, when leaving the working country, the acquired right shall be maintained (including the payment of benefit in other countries); third, the tenure right of acquiring the benefit in different countries shall be accumulated. In order to achieve these goals, the social protection to the migrant labor of each country basically adopts two methods: through the Social Security Agreement or the unilateral measures [7].

\subsection{Countries Social Security Agreements}

1) American social security agreements

Since 1978, America has had signed international social security agreements with other countries, namely the totalization agreements. This kind of agreements exempt employers or employees as multinational workers from any double insurance and double paying social security tax with the help of social security agreements between two involved countries; moreover, the agreements may also provide precautions against when an individual is unable to get benefit payments within one or both countries due to multinational works in old, disable or dead, without transferring any insurance fund. At present, America has signed totalization agreements with 24 countries, and through these agreements, it successfully eliminates the double-premium problem previously existed in two social security system. Under these agreements, migrant workers usually need to pay social security and federal medical insurance taxes in their residing countries, and their payment countries will release certificates to free them from paying social security taxes in the other country.

2) Canadian social security agreements

Canadian social security agreements provide social insurance payments for laborers retirement, disability and death. Social security agreements are deemed to insure laborers equities, regardless of residing in Canada, or in countries having social security agreements with Canada. Taking the social security agreement signed between America and Canada as the example, which was effective since August $1^{\text {st }}, 1984$, it aims to upgrade the social 
safety guarantee for laborer worked in these two countries. In addition, these agreements signed with Canada could bring many benefits to transnational migrant workers, and exempt transnational migrant workers from pay a double social security tax due to same benefit between the two countries. As for America, the agreements consist of social security tax (including American medical insurance), social insurance pension, disabled compensation and survivor insurance. While, as for Canada, the agreements are applicable to retirement pension plans and Canadian pension plans, as well as a special Quebec pension plan. Under a circumstance that laborers may have social security pensions in both America and Canada, and each separately is not eligible for retirement (tenure of length /count), and the agreements make it easy for transnational migrant workers accumulating their retirement eligibilities within the two countries, thereby to obtain their pensions.

\section{3) Europe}

Pension systems in European region mostly involve defined contribution. In fact, Social Security agreements among European countries were existed early in 1904 made between France and Italy, regarding to occupational injuries compensation, which was the first bilateral social security agreement; while the first multilateral social security agreement was made by the Scandinavian countries (Denmark, Norway and Sweden) in 1919, also regarding to occupational injuries compensation [7]. The European Social Charter passed by the European Communities on October 18, 1961, especially the Article 12, together with the European Code of Social Security passed on April 16, 1964, as well as the European Social Security Specification revised in 1990, provide protections for migrant workers in obtaining their social security payment items.

The European Convention on Social Security passed by the Council of Europe in 1972 has been perceived as the most comprehensive model for social security portability (Villars, 1981). As long as you are an EU citizen, your social security right could be retained, maintained and transferred. Therefore, EU citizens' social security payment equities will not be damaged when transferring to another country. Employment ministers of EU member countries then decided to reduce multinational employees' social security payment amounts in 2003 within the single market, and reached Social Security agreements as Luxembourg had been persuaded to drop its opposition to multinational unemployment benefit payment.

Each EU member country has its own tax system, although the pension account of most EU countries' laborers can be transferred to each other, the transfer process and transfer result still cause a lot of controversies. For example, the difference of tax system provisions in each member country causes different standard of pension account's levy tax payment and tax exemption. For instance, the Netherland's employers' insurance premium contribution can totally annul tax and be applicable to all retirement plan. Under a certain circumstances, employers' insurance premium contributions among Denmark, Belgium, Italy and France, etc. can partially annul or totally annul tax. Employees' insurance premium contributions in some countries are totally free tax, some have prescribed limit, and the upper limit of tax exemption is also different. For example, the maximum exemption of British employees' insurance premium contribution can be $15 \%$ of income. The Netherland employees' insurance premium can reduce and exempt the tax, unless the participated pension plan is not approved by Netherland Government. EU protocol Interim Agreement of European Social Security Scheme is aiming to protect the elderly, disability and survivor. Members of Council of Europe are the majority to sign this protocol, and mainly taking the European elderly, disability and survivor into account [8].

4) China's social security agreements

China's social insurance has five parts: enterprise employee medical insurance, enterprise employee pension insurance, unemployment insurance, occupational injury insurance and maternity insurance. As stipulated in the Social Insurance Law of the People's Republic of China effected since July $1^{\text {st }}, 2011$, foreigner need to have a social insurance (Article 97); pension insurance is divided into social pooling and individual accounts (Article 12); worker shall at least have 15-year insurance tenure, and hit retirement age to receive pensions monthly (Article 16); in case of involving any interregional employment, basic pension insurance could be transferred (Article 19); persons with insufficient insurance tenure for pension payment (such as rural-urban migrant workers' return, foreigners' departure) could get a lump sum amount in their individual account. At present, each worker shall pay $8 \%$ and employer $12 \%$ of his salary to pension account.

Foreigners worked in China after 2011 are subjected to the State's social security system. China has perceived Taiwan as a "province", similar to that of Hong Kong and Macao, however, the State Council has also specified citizens in Hong Kong, Macao and Taiwan as "foreigners”, and all must join in social insurance. China has signed social security agreements with Germany, South Korean, Finland, Singapore, Denmark, Spain and Switzerland, and has been negotiating with Japan, Australia and New Zealand in recent years [9]. The Sino-Germany Social Insurance Agreement exempt the worker who pays pension and unemployment insurances in other country.

5) Japan’s social security agreements 
During the process of investments and trades among Japanese enterprises, oversea expatriations are gradually intensified. With the increasing numbers of oversea employees, Japan's multinational enterprises have to provide double social insurances for their employees (expatriates still need to cover the Japanese national annuity), thus, unacquirable payment may result from a short insurance period overseas. Therefore, these enterprises expect Japanese Government to negotiate and sign Social Security agreements. And major considerations for Japanese Government in signing such kinds of Social Security agreements include: partner country have the willingness to communication, employment figure to the partner county is considerable, the signing of Social Security agreements may save a substantial of double insurance premium for both countries, social security premium within partner country is high, and expect to expend economics and trade relations with Japan in the future, etc.

In 2002, Japan only had signed Social Security agreements with Germany (effected in 2001) and Britain (effected in 2000), and its employer groups thereby suggested to sign Social Security agreements with America (maximum Japanese workforce in 2001), the Netherlands, Italy, Luxembourg (high social security premium), Canada, Australia (supposed to be negotiated with Japan), etc. [10]. And in 2011, employer groups also suggested to sign relevant Social Security agreements with China (as the increasing numbers of Japanese workers, China has implemented the Social Insurance Act since July, 2011, and expect to continuously expend trade scale between the two countries), and negotiate with India (has expended the scope of social security system) with respect to the effective date of Social Security agreements (have stipulated in the Economic Partnership Agreement between Japan and India) signed [11].

\subsection{Taiwan's Social Security for Foreign Laborers and Laborers Moved Overseas}

In accordance to Article 6 of the Labor Insurance Act, persons above 15-year-old, but under 65-year-old and employed by business units having more than 5 people shall participate in Labor Insurance; and laborers referred above include in-service foreign employees. According to this, Labor Insurance is not restricted by any nationality, but subject to whether an employer has employees less than 5. According to statistical data released by the Council of Labor Affairs in June, 2007, 97\% of foreign laborers in public institutions have labor insurances. As for foreign laborers employed under Article 8 of same regulation, together with servants and foreign family caretakers from natural person families are belong to voluntarily insured's. Due to the lack of compulsory insurance regulation, and employer's labor cost considera- tion, employer might not feel like provide Labor Insurance for its family worker, which is substituted by life insurance. And illegal foreign workers are prohibited to have Labor Insurance.

Labor Insurance payments enjoyed by foreign laborers include payments on ordinary incident insurance (maternity, injury, disability, old-age and death) and occupational incident insurance (injury, medical treatment, disability and death); the government provides certain insurance premium allowance (10\%) for employees, including foreign laborers. With respect to old-age insurance payment, there have the following stipulations (refer in Article 58 of the Labor Insurance Act): (1) The old age to $60^{4}$, with a Labor Insurance tenure attaining to 15 years, could apply for old-age annuity payment. (2) The old age to $60^{5}$, with Labor Insurance tenure not attaining to 15 years, could apply for a lump-sum old-age payment. (3) Persons with Labor Insurance tenure before 2008, and meet the following qualifications as well as requirements, could apply for a lump-sum old-age payment: a. retiree of 60-year-old (female is 55-year-old) with one-year Labor Insurance tenure; b. retiree of 55-year-old with Labor Insurance tenure attaining to 15 years; c. retiree in a same insured unit with Labor Insurance tenure attaining to 25 years; d. retiree of 50-year-old labor with Labor Insurance tenure attaining to 25 years; e. retiree of 55-year-old with five-year special nature of work experience with respect to hazard, great physical strength ${ }^{6}$ etc. approved by the central competent authorities. (4) As long as laborer is qualified for any of the above condition, he can apply for payment anytime. (5) Applicant may apply for insurance payment either in Taiwan, or abroad, therefore, foreign workers already returned to their countries have no need to head for Taiwan in applying; when in payment, may remit to an abroad account, with remittance charges borne by the insured.

In general, the working period for blue-collar foreign workers employed in Taiwan is 3-year for each term of contract, with a maximum duration of 12-year, and as long as those male foreign workers aged to 60-year-old, and female aged to 55-year-old, they could apply for a lump-sum old-age payment. However, they are difficult to be qualified for old-age annuity payment ${ }^{7}$. And only white-collar foreign laborers, such as foreign professionals dispatched by overseas enterprises in Taiwan, due to their unlimited duration, may be qualified for old-age annuity payment.

\footnotetext{
${ }^{4}$ The legal minimum retirement age will gradually increase to 65 as referred in Article 58 of the Labor Insurance Act.

${ }^{5}$ The legal minimum retirement age will gradually increase to 65 as referred in Article 58 of the Labor Insurance Act.

${ }^{6}$ When including in operations related to high temperature, abnormal pressure, elevation, precision, heavy manual etc., please refer to Article 11 of the Labor Safety and Health Act.

${ }^{7}$ Suppose they become a foreign spouse, they may have Labor Insurance tenure over 15 years.
} 
Concerning the family death and burial allowances, as stipulated in Article 43 in the original Employment Services Act, foreign laborer involved in Labor Insurance, with his family dependants dead out of implement scope of the Labor Insurance Act, shall not apply for any family death and burial allowance; No. 560 of Grand Justice 560 (July 4, 2003) also pointed out that a foreign laborer's family dependants dead out of implement scope of the Labor Insurance Act, shall not apply for any family death and burial allowance, which was constitutional. And this rule was deleted in the Employment Services Act amended on January $21^{\text {st }}$, 2002, which means that any death of parents, spouses or children of foreign workers involved in Labor Insurance after the implementation (January 23, 2002) of the Act, could apply for family death and burial allowances in accordance with provisions as stipulated in Article 62 of the Labor Insurance Act. Based on the data acquired, insurance payment cases related to foreign laborers after the death of their relatives in home countries in the year of 2010 were up to over 2,900, which were 4,000 cases in 2009, 2,680 cases in 2007, 2,300 cases in 2006, and 1,741 cases in 2005 (Liberty Times on 2011.6.7), showing more and more foreign laborers know how to preserve their rights.

Moreover, as originally stipulated in Article 12 of the Relations Ordinance between People in Taiwan and the Mainland China (hereinafter referred to as the Relations Ordinance across the Straits, published for implementation on July $31^{\text {st }}$, 1992): “Any injury, maternity or death out of implement scope of the Labor Insurance Act related to family dependants of the China people permissibly employed in Taiwan, shall not apply for any insurance payment concerned the incident.” Taiwan's Labor Insurance Bureau has pointed out on August 29, 2005 that, as released by the Council of Labor Affairs on May 24, 2005, Chinese spouse permissibly resided and employed in Taiwan by virtue of marital relation, with his family dependants dead out of implement scope of the Labor Insurance Act, could apply for family death and burial allowances, not restricted by stipulations in Article 12 of the Relations Ordinance across the Straits. Article 12 of the Relations Ordinance across the Straits (July $\left.31^{\text {st }}, 1992\right)$ was amended on July $1^{\text {st }}, 2009$, and implemented on August 14, 2009. With respect to Chinese in Taiwan for professional activity, who does not go to Taiwan for employment, are restricted to have Labor Insurance.

Taiwan nationals must comply with the provisions of local national laws when they are working in other countries, due to there's no Social Security Agreement signed between Taiwan and other countries, may double participate insurance, participate Labor Insurance of Taiwan only, participate social insurance of local nations only, or participate no insurance in both countries. The one who has double insurances may get the insurance payments of old-age benefit from both countries, or possibly only get the old-aged benefit of Labor Insurance from Taiwan; the one has no insurance of both countries shall have inadequate protection of retirement.

\section{Comparative Analysis of Considerations and Contents about Signing Social Security Agreements of Various Countries}

In the pattern of production specialization globally, American enterprises are around the world very early, and Americans are working in various countries; therefore since 1978, America signed International Social Security Agreements with other countries, in order to eliminate the problems of double paying social security tax, and adopt the so-called "totalization" to calculate the tenure that insured overseas. These agreements can prevent the situation of no claims of payments can be paid by two countries if happened old age, disability or death due to transnational working; Overseas payment is allowed but conditions vary according to different countries. According to these agreements, generally American migrant worker only has to pay the social security tax and federal Medicare tax of the country which he/she resides in, the country that the worker shall pay taxes for will issue a certificate to exempt social security tax in another country.

There are a great number of Canadians working in other countries, especially America; Its Social Security Agreement offers the payments of retirement, disability and death of labor. The tenure of reciprocal recognition between America and Canada is smooth due to similar national situations (residents can be cleared by the custom with driver license to cross the border).

Upon there are a great number of transnational labors in European countries, with the development of EU (European Union), transnational payments are more convenient, and social security system is regarded as a part of human rights, so Europe started negotiating Social Security Agreement very early (the year of 1904). [European Social Security Convention] passed by European Council in 197, advocated portable repayments of social security (defined contribution); [EU Chapter of Fundamental Rights] passed by EU in 2010 admitted and respected that everyone has rights to claim social security payments and social services in order to protect rights such as fertility, disease, occupational accident, old age, unemployment etc. However, the differences of premium, payment qualification, amount, and the applicable tax system of retirement pension still resulted from mutual transfer of the same type of pensions in European countries. This is an obstacle of success transfer. France, Germany and Norway treat immigrant or foreign labor equally, taking account of promoting the social security 
system of migrant labor.

China attracts lots of foreign labors in, in this case it can negotiate Social Security Agreement when the corresponding countries propose requirements of negotiation; China has already signed Social Security Agreements with other countries. Currently China has rules that can promote that the foreign labor should strengthen local social insurance; and this causes requirements of more countries to sign Social Security Agreement with China, though it has not been implemented positively. Sino-Germany Social Security Agreement mutually exempted the expenses of retirement insurance and unemployment insurance, its applicable period is 60 months and can be extended to 96 months, particularly one more last exemption is available (diplomatic employee can get unlimited duration of exemption through application); applicable personnel including expatriate personnel, personnel of subsidiary company, personnel without employer, sailor, diplomatic employer etc. The Provisional Measures Agreement of Mutually Exempt Payments of Retirement Insurance signed between China and South Korea is to exempt the expenses of retirement insurance mutually; applicable personnel including expatriate labor and self-employer.

The main factors for Japan to consider signing Social Security Agreement including: opponent country request negotiation, the number of employees from Japan is impressive, can save impressive double insurance premiums for enterprises from both countries through the Social Security Agreement, the premium of social security is high, the economic and trade relations between Japan and the opponent country shall be extended in the future etc. The core of applicable law of Social Security Agreement signed between Japan and other countries is national (basic) pension (annuity), the National Health Insurance is included in the agreements signed with America or Holland. Applicable personnel including employee, selfemployer, expatriate from the third country, employed sailor of international ship, diplomatic personnel; family dependents is excluded in the application in principle, can get exemption through application. Generally, the exemption period is 5 years during application period. In the aspect of payments, generally shall be regulated, overseas payment is allowable, exchange free; Adopt lump sum refund when cannot claim repayments. In the respect of tenure recognition, the recognition conditions and upper limit are regulated; the tenure recognized directly between Japan and America and between Japan and Australia mutually; the difference of social security system between Japan and Holland is large so they don't directly recognize tenure mutually.

Considerations and Contents about Signing Social Security Agreements of America, Canada, Europe, Japan and China summarized as Table 1.
Currently, most of provinces or regions in China do not mandatorily require Taiwanese employees to participate in local social insurance, and there's no mutual recognition mechanism for labor/social insurance tenure in both sides, in this case there are lots of problems with which Taiwanese who work in China are confronted such as unemployment, occupational accident, disease, retirement pension etc. These problems still depend on the guarantee of Taiwan social insurance system. However, parts of Taiwan businesses don't provide coverage of Taiwan Labor Insurance or don't provide coverage of Taiwan Labor Insurance with full-pay for expatriates according to law [12].

In the event that these Taiwanese personnel still maintain employment relationships with parent companies (so-called expatriates), it is legal to continue participating Taiwan Labor Insurance, nevertheless, if they fail to maintain the employment relationships with their parent companies (not-employ-expatriate mode), and continue participating Taiwan Labor Insurance (through trade union), it is illegal (through trade union, the insurance salary may be lower than the real salary, and employer might evade the premiums shall be paid with this). Secondly, for the insured whose insurance salary shall take account of expatriate allowance, living allowance, children's education subsidies, relocation allowance, traveling allowance etc. Yet the labor may have a different perception.

While the mode which employed by enterprises is to provide coverage of insurance in Taiwan for expatriate (due to the social insurance of China is incomplete), there happened the situation that the accident risks of expatriate are undertaken by all insured's of Labor Insurance. In addition, the one that does not maintain employment relationships with parent company in Taiwan, does not participate in Taiwan Labor Insurance, and does not participate in local social insurance either, the interrupt of Labor Insurance tenure, shall cause problems about inadequate protections for social security. Besides, China may gradually demand Taiwanese to participate in local social insurance mandatorily in future, in this case there shall have lots of problems such as whether double insurance has double assurance, the premium burden of double insurance, feasibility of alternative participation of insurance, enterprises may unwilling to provide coverage of Labor Insurance for Taiwanese etc.

\section{Policy Recommendations}

\subsection{Consideration Factors for Taiwan to Negotiate Social Security Agreement}

The growing number of Taiwanese employed overseas assists Taiwan businesses which invest overseas to reduce personnel costs, adapt to the flow trend of future 
Table 1. Considerations and main contents about signing Social Security Agreements of America, Canada, Europe, Japan and China.

\begin{tabular}{|c|c|c|c|c|c|}
\hline $\begin{array}{c}\text { Country and Region } \\
\text { Item }\end{array}$ & USA & Canada & Europe & China & Japan \\
\hline $\begin{array}{l}\text { Main factors to } \\
\text { consider signing } \\
\text { Social Security } \\
\text { Agreement }\end{array}$ & $\begin{array}{l}\text { The number of } \\
\text { employees overseas } \\
\text { is large, prevent } \\
\text { double insurance } \\
\text { premiums, ensure } \\
\text { the protection of } \\
\text { social security } \\
\text { payments for } \\
\text { Americans who } \\
\text { work overseas }\end{array}$ & $\begin{array}{l}\text { The number of } \\
\text { employees in other } \\
\text { countries is large, } \\
\text { ensure the protection } \\
\text { of social security } \\
\text { payments for } \\
\text { Canadians working } \\
\text { overseas }\end{array}$ & $\begin{array}{c}\text { The number of } \\
\text { migrant labors in } \\
\text { European countries } \\
\text { is large, promote } \\
\text { the social security } \\
\text { system for } \\
\text { migrant labors }\end{array}$ & $\begin{array}{c}\text { The number of } \\
\text { employees in other } \\
\text { countries is large } \\
\text { (Negotiation proposed } \\
\text { by China), attract lots } \\
\text { of foreign labors } \\
\text { in(requirements of } \\
\text { negotiation proposed } \\
\text { by opponent country), } \\
\text { implement of } \\
\text { Social Insurance } \\
\text { Law( requirements of } \\
\text { negotiation proposed } \\
\text { by opponent country) }\end{array}$ & $\begin{array}{l}\text { Requirements of } \\
\text { negotiation proposed } \\
\text { by opponent country, } \\
\text { the number of employees } \\
\text { in other countries is } \\
\text { impressive, save } \\
\text { impressive double } \\
\text { insurance premiums } \\
\text { for enterprises from } \\
\text { both countries, the } \\
\text { premium of social } \\
\text { security in opponent } \\
\text { country is high, the } \\
\text { economic and trade } \\
\text { relations between Japan } \\
\text { and the opponent } \\
\text { country shall be } \\
\text { extended in the future }\end{array}$ \\
\hline $\begin{array}{l}\text { Main contents } \\
\text { about signing } \\
\text { Social Security } \\
\text { Agreement }\end{array}$ & $\begin{array}{l}\text { The contents of } \\
\text { applicable social } \\
\text { security law shall } \\
\text { vary according to } \\
\text { different countries, } \\
\text { the double insurance } \\
\text { can be exempted, } \\
\text { and the recognition } \\
\text { of seniority varies } \\
\text { as per country. }\end{array}$ & $\begin{array}{l}\text { The contents of } \\
\text { applicable social } \\
\text { security law shall } \\
\text { vary according to } \\
\text { different countries, } \\
\text { the double insurance } \\
\text { can be exempted, } \\
\text { and the recognition } \\
\text { of seniority varies } \\
\text { as per country. }\end{array}$ & $\begin{array}{l}\text { Recognize the } \\
\text { insured seniority } \\
\text { among member } \\
\text { states of EU, } \\
\text { pension can be } \\
\text { portable (Defined } \\
\text { Contribution), but } \\
\text { the applicable tax } \\
\text { system of pension } \\
\text { varies as per country. }\end{array}$ & $\begin{array}{l}\text { Primarily it is about } \\
\text { exemption of } \\
\text { retirement insurance } \\
\text { expenses, applicable } \\
\text { period varies as per } \\
\text { country (at least } 60 \\
\text { months). }\end{array}$ & $\begin{array}{l}\text { The core of applicable } \\
\text { law of is national (basic) } \\
\text { pension, the double } \\
\text { insurance can be } \\
\text { exempted for } 5 \text { years, } \\
\text { the recognition } \\
\text { conditions and upper } \\
\text { limit are regulated } \\
\text { (some countries } \\
\text { recognize insured } \\
\text { seniority mutually } \\
\text { but some of them don't). }\end{array}$ \\
\hline
\end{tabular}

global labor, motivate the legalization of transnational labor, promote the economic integration of Taiwan and globe and improve government image, in this case Taiwan has economic requirements for negotiating Social Security Agreement. Especially China, the number of Taiwanese employed in China is the largest, China is also the main investee of Taiwan businesses in addition China has already put Social Insurance Act into effect, and is planning positively intake foreign labors.

Preparing administrative works already for negotiating Social Security Agreement are complicated, including statistics of the number of Taiwanese that work overseas, the situations about participating in Labor Insurance continuously, the status of employer's premium affordability, premium and payment statistics of foreign labor participated in Labor Insurance, implementations of related laws and regulations in the opponent country, integrations of various social insurances in Taiwan etc. Taiwan may be not ready. However, negotiating Social Security Agreement is the trend of all developed countries, so that Taiwan is appropriate to positively strengthen the preparations of each administrative works gradually before the negotiation of Social Security Agreement, in order to negotiate to sign Social Security Agreement at any time as soon as possible; and it is better to be dominated by Executive Yuan when negotiate, can cover relevant affairs in various central competent authorities (such as Council of Labor Affairs, Ministry of Economic Affairs, Mainland Affairs Council, and Ministry of Foreign Affairs etc.) comparatively easier.

In the event that Taiwan allow the one who works overseas neither maintain the employment relationship with its parent company in Taiwan, nor has work facts, yet can participate in Labor Insurance through trade union, or recognize the tenure of social insurance in that participated in other country as labor insurance tenure, but unable to let the labor of institution whose employees are less than 4 to enjoy coverage of labor insurance fully, there might have unjust questions.

In case propose to negotiate Social Security Agreement with China in the future, there may still encounter negative evaluations in Taiwan, such as some media may criticize the government for encouraging brain drain, closing towards to China, Taiwan hollowed by Mainland China etc.. There exists political risk due to some anti-China sentiments in society. Moreover, there shall have political sensibility that whether China is willing to negotiate Social Security Agreement with Taiwan or not, 
will China take advantage of an opportunity to ask for opening for Chinese labor come to Taiwan for working.

Due to negotiating Social Security Agreement is the trend of developed countries, although there have voices of different opinions, for the opponent countries have various degree of kindness, Taiwan have to make full communications with domestic people, if it set the purpose on negotiating Social Security Agreement, and shall consider negotiating with the opponent country which has high degree of kindness to Taiwan firstly in order to lower political risk.

\subsection{Strategies for Taiwan in Negotiating Social Security Agreement}

Strategies for Taiwan in negotiating Social Security Agreement divided into short, medium and long term, proposals as follows (reference as Table 2).

Table 2. Short, medium and long term strategies for Taiwan to negotiate Social Security Agreement.

\begin{tabular}{|c|c|c|c|c|c|}
\hline $\overrightarrow{\overrightarrow{\mathrm{g}}}$ & $\begin{array}{l}\text { Whether it is feasible for Taiwan to } \\
\text { negotiate Social Security Agreement }\end{array}$ & $\begin{array}{c}\text { Unilateral strategy } \\
\text { of Taiwan }\end{array}$ & $\begin{array}{l}\text { Contents of } \\
\text { agreement } \\
\text { shall be } \\
\text { negotiated in } \\
\text { priority if } \\
\text { negotiate }\end{array}$ & $\begin{array}{l}\text { The opponent } \\
\text { countries that } \\
\text { can be negotiated } \\
\text { with in priority } \\
\text { if negotiate }\end{array}$ & $\begin{array}{l}\text { Two sides } \\
\text { of the strait }\end{array}$ \\
\hline
\end{tabular}

Administrative and political considerations, and possible impacts, currently Taiwan still have items to be strengthened, communicated and advocated for negotiating Social Security Agreement,

But negotiating Social Security Agreements has its urgency. Therefore analyze the impacts of exempting double insurance on interested parties of labor insurance, study and draw out draft amendment of the clauses that are necessarily to be amended in labor insurance regulations, end expatriates to friendly nations for investigating business and collecting data of implementation situation and related experience, set up national forums for Social Security

Agreement propose plans of improving statistics of labor insurance and overseas employment status, offer issues that Taiwan intending to negotiate to developed countries such as Japan and America.

Continue setting up national forums for Social Security Agreement, continues sending expatriates to friendly nations for investigating business and collecting data of implementation situation and related experience, implement the improved analysis and statistics of labor insurance and overseas employment status, exchange negotiating information with Japan and America by Ministry of Foreign Affairs, amend the clause of labor insurance regulations that need amendments via legislative procedures, expect Ministry of Foreign Affairs can accomplish the negotiations with Japan and America about exempting double insurance offer China the issues that Taiwan intending to negotiate and exchange negotiating information with China by Mainland Affairs Council.

Accomplish the negotiation of exempting double insure social insurance with China.
Make statistics by Taiwan itself against the premiums that increased in labor insurance of foreigner, and quantity and amount of each payment item, in order to know balance of payments; gradually collect the number of non-expatriates of native employed overseas that are still participating in labor insurance in Taiwan, and the data of their wages and the status of payments application

The transfer insurance provisions of labor, public, army and national insurance shall be integrated again to reach a reasonable status, the seniorities of labor, public and army insurances are still have to be planned.
The exchange
of related information, the statistics on the number of come and go

Negotiate to exempt double insure social insurance.

Could plan comparatively reasonable payments of labor, public, army and national insurances in the long run.
Negotiate the recognition standard of seniority of social insurance that insured overseas.

\section{Offer negotiating intensions to \\ Japan and America actively}

Collect the statistics of the number of

Taiwanese that employed in China that come from Taiwan, the status of continuously participating in labor insurance (or national annuity), the status of employer's premium affordability, the related laws, regulations and implementations of China etc.
The opponent countries which Taiwan can actively offer negotiating intensions in priority, first is Japan, second is America. The itemsshall be negotiated in priority is the exemption of double insure social insurance; secondly is the recognition standard for recognizing the labor insurance seniority of other country that insured by native.
Exempt the non-Chinese employee who has already been insured labor insurance by Taiwanese manufacture from mandatorily participating in pension insurance of local enterprise employee, unemployment insurance and social insurance.
First is to negotiate with Could negotiate Taiwan China actively, second is recognizes the seniority negotiate with Countries of social insurance that of origin for foreign labor insured by national in in South East Asia pas- China] the recognition sively. standard in the long term. 
If negotiate Social Security Agreement, can adopt bilateral or multilateral agreement, but multilateral agreement is difficult than bilateral one, so bilateral agreement prior to multilateral agreement. In the event that Taiwan shall be unwilling or unable to negotiate Social Security Agreement, can amend laws by itself and implement unilaterally, only such strategy required avoiding unfavorably narrow the options that are available for Taiwan to negotiate.

Short-term strategy: Make statistics by Taiwan itself against the premiums that joined in Labor Insurance of foreigner, and quantity and amount of each payment item, in order to know balance of payments; gradually collect the number of non-expatriates of native employed overseas that are still participating in Labor Insurance in Taiwan, and the data of their wages and the status of payments application. Currently the individual data code of the foreigner who shall participate Labor Insurance is appropriate to add columns of nationality code (the best design is three more columns for long run application), and supervise employer offering more accurate data of foreigner such as name and the date of birth, in order to make related statistics. Secondly, the Labor Insurance Act can firstly amend, reduce or cancel the subsidies of premium provided by government.

Medium-term strategy: The transfer insurance provisions of labor, civil servant, soldier and national insurances shall be integrated further to reach a reasonable status: at present, it is common that civil servant and soldier insurances transferred to labor insurance after applying for old-age and retirement benefit, but it is rare that labor insurance transferred to civil servant and soldier insurances after applying for old-age benefit, it causes unjust voices from insured of labor insurance. The one conceives to transfer insurance shall not apply for old-age benefit together until reaching all of the retirement ages. Besides, labor, civil servant and soldier insurances shall plan "totalization" system; Currently, tenure of labor insurance and national insurance have already had "totalization" systems, but the one among labor, civil servant and soldier insurances are still have to be planned.

Long-term strategy: For promoting the feeling of social equity, can plan comparatively reasonable payments of labor, civil servant, soldier and national insurances in the long run in order to insure the security of old age, and reduce social opposites.

\section{Acknowledgements}

This research has been sponsored by the Council of Labor Affairs, Executive Yuan, Taiwan. Any opinion ex- pressed in this material shall be responsibility of the authors and does not necessarily reflect the views of the sponsor.

\section{REFERENCES}

[1] J. Avato, "Portability of Social Security and Health Care benefit in Italy,” Background Paper for Joint IDS/World Bank Research Project, 2008.

http://siteresources.worldbank.org/INTLM/Resources/390 041-1244141510600/Avato-Italy.pdf

[2] J. Avato, "Portability of Social Security and Health Care benefit in the United Kingdom," Background Paper for Joint IDS/World Bank Research Project, 2008. http://siteresources.worldbank.org/INTLM/Resources/390 041-1244141510600/Avato-UK.pdf

[3] S. Cueni, "Prerequisites for a Social Security Agreement," 2011.

www.coe.int/t/dg3/sscssr//prerequisite_Cueni.pdf

[4] A.-R. Shao, "The Actuary and Financial Assessment of Ordinary Accident Insurance Rates of Labor Insurance,” Delegated Research Report, Bureau of Labor Insurance, Council of Labor Affairs Executive Yuan, Taipei, 2012. (in Chinese)

[5] ILO, “World Social Security Report 2010-2011,” ILO, Geneva, 2011.

[6] R. Thomas, "Social Protection for Migrant Workers and their families," ISSA Regional Meeting for the Americas, San Jose, Costa Rica, 2003, pp. 27-29.

[7] U. Kulke, "The Role of Social Security in Protecting Migrant Workers: The ILO Approach,” ISSA Regional Conference for Asia and the Pacific, New Delhi, 2006, pp. 21-23.

[8] Editing Console, "Guide to Success: Current Pension Systems of America and EU,” Labor and Social Security Bi-monthly, 2005. (in Chinese) http://www.bli.gov.tw/en/sub.aspx?a=4sa\%2bubLRAsI\% 3d

[9] Y. Z. Wang and A. Wei, "Issues of China's Social Security Internationalization Development," Research Report of Chinese Academy of Social Sciences, 11 November 2005.

[10] Japan Business Federation, Japan Overseas Enterprises Association, Japan Foreign Trade Council, Inc., "Requesting a Prompt Conclusion of Social Security Agreements," 2002.

www.keidanren.or.jp/english/.../2002/055.ht

[11] Nippon Keidanren, “Proposals for Japan's Trade Strategy,” 2011. www.keidanren.or.jp//2011/030/index.html.

[12] P.-L. Hsin, X.-L. Wu and J.-H. Li, "Research on Adapting to Trade Liberalization of Labor Market Changes," Council of Labor Affairs Executive Yuan Delegated Research Report, Taipei, 2011. (in Chinese) 